\title{
BOŚNIACY PRZECIWKO IMPERIUM OSMAŃSKIEMU. BUNTY LUDNOŚCI MUZUŁMAŃSKIEJ W BOŚNI W PIERWSZEJ POŁOWIE XIX WIEKU ${ }^{1}$
}

\author{
TOMASZ JACEK LIS
}

\begin{abstract}
Bosnians against the Ottoman Empire - rebellion of the Muslim population in Bosnia in the first half of the 19th century. This paper presents the history of anti-Ottoman rebellions, which occurred in Bosnia in the first half of the 19th century. The main initiators of these uprisings were not Christians, as it happened in Serbia, but local Muslim citizens, who were not accepting Stambuls' agenda towards European parts of the Ottoman Empire. In the paper I would like to investigate some of the most important events in the history of Bosnia: Husejn kapetan Gradaščević rebellion; social turmoil of ' 30 s and ' 40 s, and the final confrontation of Herzcegovinian vezir Rizvanbegović with an army of Omer pasha Latas, who received orders to pacify riots in Bosnia and Herzegovina. The paper is based on the scientific literature, public archive documents and narratives sources - memoirs and travel diaries.
\end{abstract}

StreszCzenie. Niniejszy artykuł ma na celu zaprezentowanie historii antyosmańskich powstań do jakich doszło w Bośni w pierwszej połowie XIX w. Głównymi inicjatorami wypowiedzenia posłuszeństwa Porty nie byli jednak chrześcijanie, tak jak to miało miejsce w sąsiedniej Serbii, a wyznający islam mieszkańcy tego kraju, którym nie odpowiadała polityka Stambułu względem europejskich prowincji. W artykule zwrócono uwagę na takie wydarzenia, jak powstanie Husejna kapetana Gradaščevicia, niepokoje społeczno-polityczne z lat 30. i 40. XIX w. oraz walki między wezyrem Hercegowiny Rizvanbegoviciem a wojskami Omera paszy Latasa, w połowie XIX w. Tekst jest oparty na literaturze przedmiotu i materiałach źródłowych, pamiętnikach oraz dziennikach.

Author: Tomasz Jacek Lis, Uniwersytet Jagielloński, Instytut Historii, ul. Gołębia 13, 31-007 Kraków, Polska, t.lis@uj.edu.pl, ORCID iD: https://orcid.org/0000-0003-0188-5755

Keywords: Bosnia and Hercegovina, Bosnian beyes, Ottoman Empire, 19th century

Słowa kluczowe: Bośnia i Hercegowina, bośniaccy bejowie, Imperium Osmańskie, XIX wiek

Balcanica Posnaniensia. Acta et studia, XXVIII/2, Poznań 2021, Wydawnictwo Wydziału Historii UAM, pp. 8197, ISBN 978-83-66355-84-2, ISSN 0239-4278. Polish text with summaries in English and Polish

doi.org/10.14746/bp.2021.28.21

${ }^{1}$ Artykuł zrealizowany w ramach projektu finansowanego przez Narodowe Centrum Nauki, pt. Przemiany społeczne wśród wspólnot muzułmańskich w Bośni i Hercegowinie oraz Butgarii w drugiej potowie XIX i na początku XX wieku. Studia porównawcze (projekt nr 2020/39/B/HS3/0171). 
W najnowszych podręcznikach o historii Bałkanów, które są dostępne także na polskim rynku ${ }^{2}$, dominuje narracja, jakoby powstania antyosmańskie z pierwszej połowy XIX wieku były wyłącznie dziełem chrześcijańskich Słowian, walczących o niepodległość. Twierdzenie to jest wypadkową przynajmniej kilku czynników, takich jak propagowanie tezy o wyłącznie religijnym tle konfliktów wewnętrznych w Imperium Osmańskim, pronarodowa polityka historyczna, rozwijana przez władze XIX-wiecznych państw bałkańskich, jak również stereotypowe myślenie na temat roli i miejsca islamu na Bałkanach.

W ujęciu XIX-wiecznej historiografii greckiej i serbskiej walki wyzwoleńcze, prowadzone przeciwko Imperium Osmańskiemu, stały się przedmiotem ogólnonarodowych mitologii ${ }^{3}$. Było to o tyle oczywiste, że w pierwszej połowie XIX stulecia, gdy toczyły się powstania, zmagania Serbów a zwłaszcza Greków stały się istotnymi problemami politycznymi w ówczesnej Europie. Ze względu na zaangażowanie najważniejszych mocarstw Starego Kontynentu w problemy Imperium Osmańskiego, francuska, brytyjska czy w nieco mniejszym stopniu rosyjska opinia publiczna żywo interesowały się tym, co działo się na Bałkanach. Z pewnością ciekawość ta wynikała także faktu zaangażowania się w sprawy wyzwolenia Greków i Słowian na Bałkanach ówczesnych „celebrytów”, z brytyjskim lordem George'em Gordonem Byronem na czele 4 . Ponadto wizerunek „okrutnego muzułmanina”, walczącego z miłującym wolność Grekiem czy Serbem idealnie wpisywał się w stereotypowe postrzeganie walki kulturowej i cywilizacyjnej. Obraz ten, za sprawą swojego prostego przekazu, był utrwalany przez prasę i w praktyce powielany przez cały XIX wiek. Od tego stereotypu ,złych” Turków i „dobrych” Słowian niewolna była również polska prasa. Nie posiadając na miejscu swoich korespondentów, opierała się ona na doniesieniach prasowych z Berlina, Londynu czy Paryża, co z kolei przełożyło się na taki punkt widzenia, prezentowany przez polską opinię publiczną ${ }^{5}$. Stereotypowe spojrzenie na Bałkany, przejęte ze świata zachodniego, widać zwłaszcza w dziełach pamiętnikarskich, których autorzy często kopiowali dość powszechne schematy myślowe, obecne w publi-

2 Zob. B. Jelavich, Historia Bałkanów wiek XVIII i XIX, Kraków 2005; S. K. Pavlowitch, Historia Bałkanów (1804-1945), Warszawa 2010; L. Benson, Jugosławia. Historia w zarysie, Kraków 2011.

3 J. Bonarek, T. Czekalski, S. Sprawski, S. Turlej, Historia Grecji, Kraków 2005, s. 466-467; T. Stryjek, Wspótczesna Serbia i Chorwacja wobec własnej historii, Warszawa 2020, s. 46; Д. Ђорђевић, Историја модерне Србије 1800-1918, Beograd 2017, s. 96-97.

4 E. G. Protopsaltis, Byron and Greece, [w:] Byron's political and cultural influence in the nineteenth-century Europe, red. P. G. Trueblood, London 1981, s. 91-107.

${ }^{5}$ M.Žanin-Čalić, Jugoistočna Europa. Globalna historija, Sarajevo 2020, s. 331-332. Międzywojenna historiografia jugosłowiańska często uwypuklała krzywdy, jakie ludność prawosławna doznała ze strony muzułmanów, stawiając je na pierwszym planie w charakterystyce współistnienia religijnego w Bośni; por. V. Corović, Bosna i Hercegovina, Beograd 1925. W niektórych monografiach narracja ta obecna jest do dzisiaj, por. Ч. Антић, Н. Кецмановића, Историја Републике Српске, Banja Luka 2016. 
kacjach brytyjskich, francuskich czy niemieckich, gdzie pisano o odcinaniu głów czy okrucieństwie niespotykanym na Zachodzie ${ }^{6}$.

Obecność takiego dwubiegunowego, stereotypowego sposobu myślenia o walkach narodowowyzwoleńczych Słowian w pierwszej połowie XIX wieku należy uznać za rezultat utrwalonego w myśli europejskiej postrzegania Bałkanów w kontekście orientalizmu i wielowiekowego antagonizmu muzułmańsko-chrześcijańskiego. Schemat ten był dość popularny i często powielany nie tylko na Zachodzie, ale i w Rosji, która uważała się za protektorkę i obrończynię prawosławia, religii wyznawanej przez większość ludów walczących z Imperium Osmańskim ${ }^{7}$. Wspomniane powyżej okoliczności sprawiły, że inny obraz konfliktów, jakie miały wówczas miejsce na Bałkanach, właściwie nie mógł się przebić do powszechnej świadomości, co więcej z trudem docierał on nawet do środowisk naukowych. Z konsekwencjami tego stanu rzeczy historiografia zmagała się także w XX wieku. Dlatego stosunkowo rzadko rozpatrywano chociażby „fenomen” walk, jakie z Imperium Osmańskim prowadzili muzułmanie żyjący w jego europejskich prowincjach. W poszczególnych podręcznikach możemy przeczytać, że walki te były spowodowane przede wszystkim przez wprowadzanie reform tanzimatu, podnoszenie podatków i nadmierne ambicje lokalnych elit muzułmańskich ${ }^{8}$. Oczywiście powyższe stwierdzenia nie są błędne, ale poprzez swoją ogólnikowość nie wyjaśniają genezy tych procesów.

\section{ELITA MUZUŁMAŃSKA W BOŚNI}

Z pewnością warto bardziej szczegółowo przyjrzeć się temu, co działo się na Bałkanach w pierwszej połowie XIX wieku, gdzie bunty bejów zdarzały się nie rzadziej niż powstania ludności chrześcijańskiej. W tym przypadku chciałbym skupić się na analizie buntów muzułmańskich przeciwko władzy sułtana, wzniecanych na

6 B. Jezernik, Dzika Europa. Bałkany w oczach zachodnich podróżników, Kraków 2007, s. 125126. Relacje na temat powstania w Hercegowinie (1875) m.in. Hercegowina, „Kurier Poznański” 1875, t. 17, nr 197 (08.29.1875); „Dziennik Poznański”, t. 17, nr 267 (11.21.1875); por. T. J. Lis, Bosna i Hercegovina u očima Poljaka - poljski putopisi o Bosni i Hercegovini u Austrougarskom razdoblju, „Prilozi. Univerzitet u Sarajevu. Institut za Historiju” 2018, nr 48, s. 102.

7 Edward W. Said pisał np. o barbarzyństwie, które w oczach Europejczyków od średniowiecza kojarzyło się ze społecznością muzułmańską; E. W. Said, Orientalizm, Warszawa 1991, s. 101-103. To myślenie miało również swoje przełożenie na obraz Imperium Osmańskiego wśród narodów w Europie środkowo-wschodniej w XIX i XX w.; por. J. Malečkova, ,, The Turk” in the Czech imagination (1870s-1923), Leiden-Boston 2020. Z kolei wśród argumentów przeciwko angażowaniu się Rosji w sprawy Bałkanów wymieniano obecność wielu muzułmanów, zamieszkujących zwłaszcza jej wschodnią część. Obawiano się, że w razie wojny z Portą mogliby oni stanowić coś w rodzaju „piątej kolumny”; A. Heraclides, A. Dialla, Humanitarian intervention in the long nineteenth century, Manchester 2015, s. 170.

8 S. K. Pavlowitch, Historia Bałkanów, s. 84; B. Jelavich, Historia Bałkanów, s. 279. Oficjalnie reformy zwane tanzimatem realizowano od 1839 roku, po opublikowaniu fermenu sułtana. Natomiast L. Benson określa tym mianem wszystkie reformy, prowadzone w Turcji osmańskiej w XIX wieku; L. Benson, Jugosławia, s. 9. 
obszarze Bośni ${ }^{9}$. Ze względu na swoją charakterystykę historyczno-kulturową kraj ten stanowił swoisty unikat na mapie prowincji Imperium Osmańskiego, z drugiej strony przyjrzenie się jego dziejom pozwoli lepiej zrozumieć, dlaczego muzułmanie z Bałkanów zbrojnie występowali przeciwko sułtanowi w XIX wieku. Bośnia w osmańskiej strefie wpływów znalazła się w XV wieku. Pomimo dyskusji, czy przyjęcie islamu miało tam charakter nagły i masowy czy było procesem długotrwałym przyjmuje się, że mniej więcej od XVI wieku tamtejszą elitę stanowiła rdzenna ludność wyznająca islam, zwana bejami. Bośniaccy muzułmanie w XVI i XVII wieku znani byli przede wszystkim jako doskonali wojskowi, sprawdzający się zwłaszcza w walkach prowadzonych na ziemiach europejskich. Znali miejscowe obyczaje, język i topografię, dzięki czemu odnosili sukcesy militarne, a tym samym zyskiwali uznanie w Stambule. Bośnia wkrótce po osmańskim podboju stała się najbogatszą europejską częścią Porty, a wiek XVI w historiografii bośniackohercegowińskiej uznawany jest za „złoty okres" "10. Najważniejszym symbolem tego czasu jest monumentalna budowla sakralna, meczet Gazi Husref-beja w Sarajewie ${ }^{11}$.

Wraz z pierwszymi niepowodzeniami militarnymi Porty, Bośnia zaczęła jednak tracić na znaczeniu. Porażki, jakie Imperium Osmańskie ponosiło pod koniec XVII stulecia w pierwszej kolejności odbiły się niekorzystnie na jej sytuacji. I tak, Bośnia stała się celem działań armii Eugeniusza Sabaudzkiego. Austriacki książę, uważany przez Chorwatów za wyzwoliciela (osloboditelj), dla bośniackich muzułmanów uchodził za okrutnego zdobywcę, który w trakcie kampanii wojennej wymordował wiele osób i niszczył miasta, w tym Sarajewo, które zostało w dużej części strawione przez pożar. Ofensywa Eugeniusza przyniosła nie tylko zniszczenia materialne, ale i doprowadziła do regresu demograficznego w Bośni. Wraz z cofającymi się wojskami austriackimi uciekała stamtąd ludność chrześcijańska. Ostatecznie traktat pokojowy z Karłowic (1699) doprowadził do zmiany północnych granic Imperium Osmańskiego. Musiało ono oddać większość terenów przygranicznych, leżących w Slawonii czy Dalmacji, granica z monarchią Habsburgów została oparta na rzece Sawie ${ }^{12}$. Wydarzenia te spowodowały, że Bośnia zyskała status kraju pogranicz-

9 Podział na Bośnię i Hercegowinę ugruntował się w źródłach począwszy od lat trzydziestych XIX wieku, wraz ze stworzeniem instytucji określanej jako wezyr hercegowiński (de facto nie posiadał on wszystkich kompetencji wezyra).

10 P. Wróbel, Krzyż i Pólksiężyc. Zachodnie Bałkany wobec Turcji w latach 1444-1463, Kraków 2000, s. 108-121; M. Handžić, Islamizacija Bosne i Hercegovine i porijeklo bosansko-hercegovačkih muslimana, Sarajevo 1940, s. 19-21; M. Imamović, Historija Bošnjaka, Sarajevo 2007, s. 142, 249-255; P. Wróbel, Kontrowersje wokót podboju i islamizacji Bośni. Przyczynek do krytyki tzw. „,polityki historycznej”, „Balcanica Posnaniensia. Acta et studia”, 2012, t. 19, s. 87; ibidem, Oblicza islamizacji na terenach Bośni w XV i 1 połowie XVI wieku, „Balcanica Posnaniensia. Acta et studia” 2011, t. 18, s. 83-99; A. Jawoszek-Goździk, Bejowie, [w:] Leksykon idei wędrownych na stowiańskich Batkanach XVIIIXXI wiek, red. G. Szwat-Gyłybowa, D. Gil, L. Miodyński, t. 10, Warszawa 2020, s. 23-26; B. Zlatar, Zlatno doba Sarajeva (XVI stoljeće), Sarajevo 1996, s. 38.

11 Ibidem, s. 121.

12 M. Pelc, Utilissimus reipublicae princeps - Eugen Savojski i retorika barokne medalje, „Radovi Instituta za povijest umjetnosti” 2020, nr 44/1, s. 91; F. Ademović, Princ Palikuća u Sarajevu, Sarajevo 
nego, a więc i bezpośrednio narażonego na wrogie ataki ze strony sąsiada. Miało to daleko idące konsekwencje społeczne, ponieważ zasłużeni wojskowi bośniaccy nie mogli dłużej pełnić roli „włóczni proroka”, która zadawała ciosy w trakcie kampanii wojennych. W okresie defensywy sił osmańskich stali się oni główną tarczą ochronną europejskich granic Turcji ${ }^{13}$. W rejonie przygranicznym funkcjonowali tzw. kapetanowie $^{14}$, którzy oprócz funkcji wojskowych pełnili rolę o charakterze policyjnym i byli głównymi gwarantami bezpieczeństwa dla miejscowej ludności. Wewnątrz Bośni funkcje te leżały w gestii ajanów, którzy podobnie jak kapetanowie byli członkami najwybitniejszych miejscowych rodów. W Bośni, która stanowiła europejskie peryferium Turcji osmańskiej, na szczególnym znaczeniu zyskała feudalizująca się lokalna elita muzułmańska. Co więcej, muzułmanie zyskali demograficznie na wydarzeniach z przełomu XVII i XVIII wieku, gdy ówczesne migracje spowodowały poważny spadek liczby ludności chrześcijańskiej. Bośniaccy muzułmanie byli nie tylko uprzywilejowani ze względu na wyznawaną religię i swoją pozycję polityczną, ale stopniowo zyskiwali przewagę demograficzną ${ }^{15}$.

Dopóki Imperium Osmańskie prowadziło politykę opartą na ekspansji, dopóty prominentni wyznawcy islamu z Bośni bogacili się na podbijanych terenach. Koniec podbojów oznaczał potrzebę pozyskiwania środków w inny sposób. Dla związanych z terenami pogranicznymi kapetanami najbardziej dochodowym interesem była ziemia (timar), którą otrzymywali od sułtanów w formie zadośćuczynienia za gotowość do walki. W konsekwencji poszczególne rody kapetanów w ciągu kilku pokoleń zmieniły swoją charakterystykę społeczno-ekonomiczną. Z wojskowych i zdobywców, którzy często zmieniali miejsca zamieszkania, przekształcali się oni w posiadaczy ziemskich. Konieczność stałej obrony granic spowodowała, że kapetanowie utożsamiali się z placówkami, których strzegli. Byli odpowiedzialni za bezpieczeństwo nie tylko granic Imperium Osmańskiego, ale i ziem, które uważali za swoją własność. Poczucie związku kapetanów z poszczególnymi rejonami (tzw. kapetaniami) spowodowało, że z czasem, przy braku kontroli ze strony władz centralnych, przechodziły one na własność danego rodu a wojskowa funkcja kapetana zyskała charakter dziedziczny. Podobnie rzecz miała się z ajanami. Proces umacniania władzy kapetanów i ajanów, wywodzących się z lokalnych społeczności, na terenach gdzie mieli pełnili służbę wojskową był groźny z punktu widzenia Stambułu ${ }^{16}$. Z drugiej strony koniecz-

1997, s. 11-15; L. Đaković, Političke organizacije bosanskohercegovačkih katolika Hrvata, (I dio: do otvaranja Sabora 1910), Zagreb 1985, s. 47; D. Gibas-Krzak, Bośnia i Hercegowina: Determinanty dziejów. Pomiędzy Serbami, Chorwatami a supremacja muzulmanów, Częstochowa 2016, s. 61.

13 H. Kreševljaković, Kapetanje u Bosni i Hercegovini, [w:] H. Kreševljaković, Izabrane Djela I, Sarajevo 1991, s. 23.

14 Kapetanowie - formacja wojskowa funkcjonująca w Imperium Osmańskim, której zadaniem była ochrona terenów granicznych.

15 M. R. Hickok, Ottoman military administration in eighteenth-century Bosnia, Leiden-New YorkKöln, 1997, s. 45.

16 N. Močanin, Postanak muslimanskog plemstva u Bosni i Hercegovini: zanemirani aspekti, „Rad Hrvatske akademije znanosti i umjetnosti. Razred za društvene znanosti” 2017, nr 529, s. 84-86; 
ność utrzymywania aktywnego wojska na granicach wymuszała jednak daleko posuniętą tolerancję względem partykularnych działań poszczególnych przedstawicieli miejscowej elity. O tym, że kapetanowie byli sułtanowi niezbędni, przekonano się podczas wojny z lat 1737-1739, gdy dzięki broniącym bośniackiego pogranicza bejom zdołano odeprzeć atakujące wojska austriackie. Co więcej, z ich usług korzystano także podczas walk, jakie imperium toczyło na Bliskim Wschodzie ${ }^{17}$.

System kapetanii dawał gwarancje utrzymania wątłego bezpieczeństwa na europejskich peryferiach Imperium, ale i utrwalał wśród bośniackich muzułmanów przekonanie o ich wielkim znaczeniu militarnym dla państwa osmańskiego. Chociaż ejalet Bośni, a od XIX wieku paszalik Bośni podlegały wezyrowi wyznaczanemu przez sułtana i stacjonującemu w stołecznym Travniku, pozycja miejscowych bejów była na tyle silna, że mogli oni prowadzić własną politykę bez oglądania się na Stambuł. Wraz z pogłębianiem się kryzysu osmańskich struktur państwowych co bardziej wpływowi bośniaccy muzułmanie zadawali sobie pytanie, czy korzystne dla nich było dalsze trwanie w ramach słabnącego Imperium Osmańskiego? Wątpliwości były tym większe, że wraz ze słabnięciem Turcji w rejonach przylegających do granicy narastały niepokoje natury społeczno-politycznej i religijnej, które coraz bardziej różnicowały miejscową ludność. W wiek XIX muzułmańskie elity Bośni i Hercegowiny weszły jednak jako grupa o dość spójnej charakterystyce społecznej. Na gruncie lokalnym nie posiadała ona naturalnych konkurentów w postaci innych wspólnot wyznaniowych, np. chrześcijan ${ }^{18}$.

\section{POWSTANIE KAPETANA GRADAŠČEVICIA}

Jednym z pierwszych reorganizatorów państwa, który starał się ograniczyć szerokie przywileje miejscowych elit, dominujących w poszczególnych częściach Turcji był sułtan Selim III, ale dopiero za panowania Mahmuda II (1808-1839) doszło do zasadniczych zmian w organizacji struktur wojskowych. W 1826 roku zlikwidował on formacje janczarów, które były podstawą środowisk wrogo nastawionych wobec wszelkich prób modernizacji państwa. Dla muzułmańskich elit z europejskich prowincji Imperium Osmańskiego, w tym także Bośni, zmiany te stanowiły zagrożenie dla ich dotychczasowej pozycji. Janczarzy obawiali się utraty przywilejów ekonomicznych i politycznych, łącznie z presją wywieraną na władze centralne za pomocą intryg

M. Imamović, Historija države i prava u Bosni i Hercegovini, Sarajevo 1999, s. 215-216. Od końca XVI w. w Bośni zauważalny był proces dziedziczenia lenna, które otrzymywali w nagrodę spahijowie; A. Aličič, Pokret za autonomije Bosne od 1831. do 1832. godine, Sarajevo 1996, s. 42.

17 M. Imamović, Historija Bošnjaka, s. 306; E. Pelidija, O Bošnjačkoj eliti XVIII stoljeća, „Znakovi vremena" 2005, nr 26-27, s. 126-128.

18 S. Džaja, Konfesjonalnost i nacjonalnost Bosne i Hercegovine. Predemancipijsko razdoblje 14631804, Mostar 1999, s. 97; T. Rawski, Boszniacki nacjonalizm. Strategia budowania narodu po 1995 roku, Warszawa 2019, s. 50. 
dworskich i wzniecanych lokalnie buntów. Co więcej, w swoim oporze przeciwko reformom mogli oni liczyć na poparcie ulemów, islamskiego duchowieństwa, które de facto było jedyną wykształconą grupą społeczną wśród muzułmanów. Ulemowie, tak jak janczarzy, byli przeciwni zarówno reformom Selima III, jak i Mahmuda II. Decyzje zmierzające do wyeliminowania wpływu janczarów na sprawy państwowe spotkały się z oburzeniem elit muzułmańskich zwłaszcza w Sarajewie, który natenczas był drugim co do znaczenia ośrodkiem w kraju. Należy jednak pamiętać, że część tamtejszych bejów, zwłaszcza niezwiązanych bezpośrednio z wojskiem, popierała politykę sułtana i jego wezyrów, chcąc ograniczyć samowolę zmilitaryzowanych rodów w relacjach na polu lokalnym ${ }^{19}$.

Liderzy wojskowi w Bośni, kapetanowie i ajanowie, obawiali się, że spotka ich ten sam los, co janczarów. W początkowej fazie rozliczeń z sułtanem znaczna ich część opowiedziała się po stronie buntowników. Wśród nich był Husejn kapetan Gradaščević z Gradačaca, potomek znakomitego rodu, w którego rękach od kilku pokoleń znajdowała się funkcja kapetanów. Jak wskazuje bośniacki historyk Husnija Kamberović, Gradaščević zadeklarował swoje poparcie dla janczarów i w latach 1827-1828 wystąpił zbrojnie przeciwko wezyrowi Abdurrahimowi paszy w Travniku. Z drugiej strony, po wygaszeniu tego konfliktu podjął jednak współpracę z paszą w kierunku uspokojenia ówczesnej sytuacji. Przykład ten był dość reprezentatywny, poszczególni dowódcy opuszczali bowiem buntowników zarówno w obawie przed krwawymi represjami ze strony wojsk wezyra, jak i za sprawą przywilejów, które miały ich przekonać do lojalności względem sułtana ${ }^{20}$.

Fizyczne wyeliminowanie janczarów, choć okupione wielkim trudem, nie przyniosło oczekiwanego przez Stambuł pokoju. Co prawda siejącego grozę Abdurrahima paszę zastąpił łagodniejszy w swojej polityce Mehmed Namik pasza, ale sytuacja polityczna w Bośni była bardzo chwiejna. Na skutek traktatu pokojowego w Adrianopolu, który kończył wojnę rosyjsko-turecką (1828-1829) ${ }^{21}$, sułtan został zmuszony do kolejnych ustępstw na rzecz chrześcijan, zamieszkujących tereny państwa osmańskiego. Na sytuację Bośni duży wpływ miała zapowiedź przyznania autonomicznemu Księstwu Serbii części ziem, której wchodziły w skład osmańskiej prowincji. Obietnicy tej sułtan nie konsultował z bośniackimi muzułmanami, którzy poczuli się

19 S. Džaja, Konfesjonalnost $i$ nacjonalnost Bosne i Hercegovine, s. 95. W XVIII wieku Bośnia była areną wielu wystąpień przeciwko władzy centralnej. Do niepokojów dochodziło głównie z powodów pogarszającej się sytuacji ekonomicznej; M. Hadžijahić, Bune i ustanak u Bosni sredinom XVIII stoljeća, „Historijski zbornik” 1980-1981, t. 33-34, s. 103; S. S. Shaw, E. K. Shaw, Historia Imperium Osmańskiego i Republiki Tureckiej, Warszawa 2012, s. 25-31; F. Karčić, Studije o šerijatskom pravu i institucijama, Sarajevo 2011, s. 334-341; A. Aličič, Pokret za autonomije Bosne od 1831. do 1832. godine, s. 159-161.

20 Ibidem, s. 161-162; H. Kamberović, Husein-Kapetan Gradaščević (1802-1834). Biografija, Gradačac 2002, s. 25, 27; F. Sel Turhan, The Ottoman Empire and the Bosnian uprising. Janissaries, modernisation and rebelion in the nineteenth century, London-New York 2014, s. 95-97.

21 W. Morawski, S. Szawłowska, Wojny rosyjsko-tureckie od XVII do XX wieku, Warszawa 2006, s. 111-128. 
urażeni i jednocześnie zagrożeni. Dodatkową „kością niezgody” pomiędzy sułtanem a kapetanami i ajanami były dalsze próby reform w kierunku unifikacji struktur wojskowych. Miejscowe elity odebrały to jako zamach na swoją odrębność, którą cieszyły się przez całe stulecie. Wydarzenia te były bezpośrednią przyczyną wybuchu powstania przeciwko Turkom osmańskim w 1830 roku, na czele którego stanął wspomniany wcześniej Husejn kapetan Gradaščević. Pomimo młodego wieku, dzięki wcześniejszych dokonaniom i przynależności do cenionego rodu, był on rozpoznawalny wśród bejów i cieszył się popularnością. Kapetania Gradačac, której przewodził była jedną z najbogatszych, w związku z czym budził on dość powszechny szacunek ${ }^{22}$.

$\mathrm{Z}$ literatury wyłania się postać $H$. Gradaščevicia jako przywódcy odważnego i zdeterminowanego, potrafiącego zjednywać sobie ludzi. Dzięki tym cechom udało mu się zyskać poparcie sporej części możnych bejów, którzy w grudniu 1830 roku obrali go za przywódcę ruchu sprzeciwiającego się polityce Stambułu. Kilka miesięcy później w Tuzli przewodził on spotkaniu podczas którego, jak się przyjmuje, został wyartykułowany sprzeciw wobec ustępstw na rzecz Serbii. Według ówczesnego gubernatora Dalmacji barona Franja Tomašića bejowie zażądali od sułtana i jego bośniackiego namiestnika, aby unieważnili wcześniejsze decyzje w sprawie autonomicznego księstwa, szczególnie tych, które dotyczyły uszczuplenia terytorium Bośni. Co więcej, oczekiwali oni zlikwidowania zwierzchnictwa wezyra nad Bośnią i wprowadzenia autonomicznych władz krajowych, które powinny być wybierane przez miejscowych bejów. Zaznaczono, że Bośnia miała pozostawać w granicach Porty i płacić roczny trybut na rzecz sułtana. Do tej pory nie ma pewności, czy relacja dalmatyńskiego gubernatora była w pełni wiarygodna, nie należy jednak wątpić, że działania zbuntowanych bejów miały na celu znaczące ograniczenie zakresu władzy przedstawicieli sułtana ${ }^{23}$.

Powstanie kapetanów i ajanów pod wodzą H. Gradaščevicia nie było pierwszym wystąpieniem zbrojnym przeciwko władzy centralnej, ale znalazło należne miejsce w dziejach politycznych Bośni. Wszystko za sprawą sukcesów, jakie udało się osiągnąć powstańcom, a także dzięki na poły legendarnym przekazom, w które obrosły omawiane wydarzenia. „Smokowi z Bośni” (Zmaj od Bosne), jak nazywano H. Gradaščevicia, przypisywano rolę przywódcy muzułmańskiego, który w kolejnych dekadach nabierał charakteru lidera o wymiarze ponadlokalnym i ludowym.

22 F. Sel Turhan, The Ottoman Empire and the Bosnian uprising, s. 107-108; M. Imamović, Historija Bošnjaka, s. 333-334; N. Malcolm, Bosnia: a Short history, London 1994, s. 121; S. Šehić, Zmaj od Bosne. Husein-Kapetan Gradaščević između legende i povijesti, Wuppertal 1994, s. 18; D. Gibas-Krzak, Zmierzch panowania tureckiego na Bałkanach. Polityczne, społeczno-kulturowe i militarne uwarunkowania schyłku władania Bośnią i Hercegowina przez Osmanów, „Balcanica Posnanensia. Acta et studia” 2015, nr 22/2, s. 25. Bejowie sprzeciwiali się m.in. nowemu umundurowaniu, które było wzorowane na zachodnioeuropejskim, twierdząc, że było ono niezgodne z zasadami islamu; F. Sel Turhan, The Ottoman Empire and the Bosnian uprising, s. 171-172.

23 H. Kamberović, Husein-Kapetan Gradaščević, s. 42; H. Kreševljaković, Husejn kapetan-Gradaščević. Zmaj od Bosne, Sarajevo 1931, s. 12. 
Pod koniec XX wieku percepcja tej postaci została przekonstruowana w kierunku uwzględnienia jej w panteonie bohaterów boszniackiej idei narodowej. Motywy związane z dokonaniami H. Gradaščevicia pojawiać się zaczęły w literaturze i kulturze od lat 80. XIX w. kiedy to zaczęto promować odrębność narodową muzułmanów w Bośni i Hercegowinie. Jedna z głównych ulic stolicy kraju, Sarajewa zyskała nazwę ulicy Zmaja od Bosne ${ }^{24}$. Niestety brakuje wiarygodnych studiów historycznych nad tą postacią. Wymogi naukowości spełniają w tym przypadku biografie autorstwa Husniji Kamberovicia i Hamdiji Kreševljakovicia. Zmitologizowane ujęcia tej postaci odnaleźć można w popularnonaukowych publikacjach Sadika Šehicia czy Nadiry Aličič ${ }^{25}$.

Część bośniackich historyków przedstawia powstanie z lat 1831-1832 jako pierwszą w dziejach próbę walki muzułmanów z Bośni o uzyskanie statusu autonomii, porównując te działania z ówczesnymi dokonaniami Serbów ${ }^{26}$. Bezsprzecznie Hussejn kapetan Gradaščević wraz ze swoimi zwolennikami walczył o uniezależnienie się od sułtana, ale jego działania miały na celu przede wszystkim obronę interesów bejów jako uprzywilejowanej grupy społecznej. Nie istnieje żadna przesłanka, jakoby powstańcy zamierzali doprowadzić do zniesienia powinności feudalnych czy byli zdeterminowani tworzyć odrębne struktury o charakterze parapaństwowym. Ponadto pomysły H. Gradaščevicia spotkały się z opozycją także wśród bejów, szczególnie z obszaru Hercegowiny. Mowa o Alim paszy Rizvanbegoviciu, który wraz z grupą miejscowych dowódców wystąpił zbrojnie przeciwko „Smokowi”, wykazując się lojalnością wobec sułtana ${ }^{27}$.

Chociaż uproszczeniem jest sprowadzać antagonizm pomiędzy A. Rizvanbegoviciem a H. Gradaščeviciem do rywalizacji pomiędzy rodami i klanami z Bośni oraz Hercegowiny, z pewnością wydarzenia te stanowiły sprzyjającą okoliczność dla samego Alego paszy jak i jego zwolenników. Pozyskał on wdzięczność ze strony sułtana, a także liczne przywileje. A. Rizvanbegović stanowił przykład polityka rozważnego, który zdawał sobie sprawę, że poparcie dla „pospolitego ruszenia” na czele z H. Gradaščeviciem wcześniej czy później doprowadzi do krwawego terroru ze strony wojsk sułtańskich. Poza tym Hercegowina, jak i tamtejsi muzułmanie różnili się nieco od swoich współziomków z Bośni pod względem stosunku do autonomistycznych aspiracji wyrażanych przez poszczególne rody kapetanów. Sam Ali pasza raczej nie utożsamiał się z tymi poglądami. Obawiał się natomiast nadmiernego

24 K. Kujawa, ,Smok z Bośni” w tradycji bośniackich muzułmanów wczoraj $i$ dziś, „Balcanica Posnanensia. Acta et studia” 2010, t. 17, s. 183-192.

25 Zob. N. Kujraković, Vakuf Husein-Kapetana Gradaščevića, „Anali Gazi-husref begove biblioteke" 2009, nr 29-30, s. 65.

26 Powstanie H. Gradaščevicia jest opisywane przez część współczesnych historyków boszniackich w kategoriach walki o autonomię: A. Aličič, Pokret za autonomiju Bosne, s. 174; D. Čaušević, Pravno-politički razvitak Bosne i Hercegovine. Dokumenti sa komentarima, Sarajevo 2005, s. 131.

27 H. Grandits, Multikonfesjonalna Hercegovina. Vlast i lojalnost u kasnoosmanskom društvu, Sarajevo 2014, s. 42. 
wzrostu roli kapetanów i zdawał się faworyzować ideę reformowania stosunków politycznych w Bośni pod auspicjami sułtana. Dlatego udzielił on poparcia obalonemu wezyrowi Namikowi paszy oraz jego następcy Mahmudowi Hamdiemu paszy. Z kolei H. Gradaščević, nieuznawany przez Stambuł, po kilku miesiącach sukcesów militarnych zaczął odnosić pod koniec 1831 roku kolejne klęski. Nie zdołał przekonać do swoich działań bejów z ziem macedońskich i albańskich, choć także i oni buntowali się przeciwko próbom reform w państwie. Ostatecznie ratował się ucieczką z kraju. Schronił się w monarchii Habsburgów, skąd powrócił do Turcji, próbując bezskutecznie rozmawiać z sułtanem o sprawach Bośni. Zmarł w niewyjaśnionych okolicznościach w 1834 roku $^{28}$.

\section{„ZBUNTOWANA BOŚNIA” \\ W LATACH TRZYDZIESTYCH I CZTERDZIESTYCH XIX WIEKU}

W tym samym czasie A. Rizvanbegović nie tylko zyskał wdzięczność sułtana za okazaną lokalność, ale i stał się najbardziej wpływową postacią wśród miejscowych elit. W 1833 roku triumfalnie powrócił on do rodzinnej Hercegowiny, gdzie odczytał w Mostarze ferman, w którym sułtan obdarował go godnością wezyra Hercegowiny ${ }^{29}$. Urósł do rangi najpotężniejszego człowieka w kraju i utrzymywał posłuch, stosując rządy silnej ręki oraz prowadząc roztropną politykę względem administratorów sułtańskich. Jak wynika z relacji autorstwa jednego z agentów austriackich, działającego w miejscowości Livno, ówczesna Hercegowina była miejscem bardziej stabilnym politycznie i ekonomicznie od Bośni, skąd co chwila dochodziły informacje o niepokojach wśród ludności muzułmańskiej ${ }^{30}$. A. Rizvanbegović traktował Hercegowinę jak księstwo rodowe. Starał się rozwijać miejscowe rolnictwo, wspierał tworzenie upraw oliwek i cytrusów, a także finansował budowę kanałów irygacyjnych $^{31}$. Wszystkie stanowiska obsadzał krewnymi, co frustrowało lokalnych be-

28 W kwietniu 1831 roku H. Gradaščević przejął Travnik skąd ewakuował się namiestnik osmański. Tam obwołano go bośniackim wezyrem, co znalazło potwierdzenie kilka miesięcy później w Prisztinie, gdzie H. Gradaščević szukał wsparcia wśród bejów albańskich. H. Kamberović, Husein-Kapetan Gradaščević, s. 43-44. Por. także: A. Jabłonowski, Pisma Aleksandra Jabłonowskiego, t. 5 (Słowiańszczyzna południowa oraz Wołosza i Albania), Warszawa 1911, s. 68-71; H. Kapidžić, Ali-paša Rizvanbegović i nijegovo doba, Sarajevo 2001, s. 55 i 61; L. Maier, Die Grenze zwischen dem Habsburgerreich und Bosnien um 1830. Von einem Versuch, eine friedlose Region zu befriede, „Jahrbücher für Geschichte Osteuropas” 2003, nr 51, s. 389; H. Grandits, Multikonfesjonalna Hercegovina, s. 44.

29 Należy pamiętać, że tytuł wezyra Hercegowiny nie był równy pozycji wezyra Bośni. A. Rizvanbegović pełnił funkcję zarządcy sandžaku Hercegowiny. H. Kapidžić, Ali-paša Rizvanbegović i nijegovo doba, s. 66.

30 Prijatel A. do Ivo Vuleticha (17.05.1846), [w:] G. Šljivo, Bosna i Hercegovina u XIX stoljeću u spisama stranih izvještača, Tešanj 2008, s. 128-129.

31 J. Branković, Mostar 1833-1918, Sarajevo 2009, s. 47-48. 
jów i agów, powiązanych z innymi rodami. Aby ograniczyć zagrożenie z ich strony, A. Rizvanbegović nie wahał się, zdaniem niektórych historyków, negocjować przeciwko poszczególnym oponentom z prawosławnym księciem Piotrem II Njegošem z Czarnogóry. Przypuszcza się, że celem tych kontaktów było wyeliminowanie Smaila agi Čengicia, który najpierw walczył przeciwko H. Gradaščeviciowi, a po jego upadku krytykował S. Rizvanbegovicia za nepotyzm ${ }^{32}$. Smail aga Čengić zginął, walcząc z Czarnogórcami (1840).

W rok po jego śmierci faktycznie doszło do podjęcia współpracy pomiędzy S. Rizvanbegoviciem a władyką czarnogórskim. W Dubrowniku podpisano układ pokojowy, gdzie ustalono, że żadna ze stron nie zażąda rewizji dotychczasowej granicy czarnogórsko-hercegowińskiej, Porta, przy pomocy arbitrów z Rosji i Austrii, miała rozstrzygnąć przyszłość twierdzy w Grachowie, wobec której Hercegowina i Czarnogóra rościły sobie pretensje. Ponadto uzgodniono, że uskocy opuszczą terytorium osmańskie i przeniosą się na tereny podległe władyce czarnogórskiemu. Układ pokojowy pozwolił unormować napiętą sytuację na granicy czarnogórsko-hercegowińskiej i obowiązywał do śmierci Rizvanbegovicia w 1851 r. Warto zauważyć, że stanowił on pierwszy przypadek w dziejach XIX-wiecznej Bośni i Hercegowiny, gdy prominentny muzułmanin (bej) pochodzenia słowiańskiego porozumiał się ze słowiańskim prawosławnym władcą. Oczywiście układ ten został podpisany pod wyraźnym naciskiem Austrii i Rosji, niemniej jednak podobne porozumienie nie miało precedensu w przeszłości. Ali pasza wystąpił wówczas jako władca niezależny od Stambułu, który był w stanie prowadzić własną politykę ${ }^{33}$.

Stosunki między S. Rizvanbegoviciem a Stambułem ewoluowały. Początkowo cieszył się on wsparciem ze strony sułtana. $Z$ czasem jego samodzielność i brak chęci do podjęcia reform w duchu tanzimatu zaczęły irytować następcę Mahmunda II, Abdülmecida I (1823-1861), który wstąpił na tron w 1839 roku. Dla nowego sułtana wezyr Hercegowiny stał się nazbyt samodzielny. Alego paszę zwalczała również Austria, obawiając się jego sojuszu z Czarnogórą. Austriakom nie odpowiadała także brutalność wezyra względem ludności katolickiej, która jednak wynikała nie tyle ze względów religijnych, co z chęci doraźnego zysku. Należy pamiętać, że S. Rizvanbegović pozwalał katolikom swobodnie praktykować swoją religię i budować kościoły, a w jego bezpośrednim otoczeniu nie brakowało franciszkanów. Co więcej, widząc dla siebie polityczną korzyść działał on na rzecz biskupa Franja

32 A. Zheliazkova, The penetration and adaptation of islam in Bosnia from the fifteenth to the nineteenth century, „Journal of Islamic Studies” 1994, nr 5/4, s. 204; H. Kapidžić, Ali-paša Rizvanbegović i nijegovo doba, s. 79, 82 .

33 H. Grandiets, Multikonfesjonalna Hercegovina, s. 253-254; H. Kapidžić, Ali-paša Rizvanbegović i nijegovo doba, s. 105-106; L. Durkowicz-Jakszicz [Durković-Jakšič], Petar II Petrović-Njegoš (18131851), Warszawa 1938, s. 81-88. 
Barišicia $^{34}$, którego wspierał w konflikcie z miejscowym duchowieństwem hercegowińskim $^{35}$.

Także w Bośni kolejni wezyrowie, przysyłani ze stolicy, musieli zmagać się z oporem ze strony miejscowych bejów. W 1835 roku energicznemu wezyrowi Mehmedowi Vedžihi paszy udało się ostatecznie zlikwidować instytucję kapetanów i wprowadzić jednolitą komendę wojskową. Gdy jednak rok później zapadł rozkaz powołania nowego rocznika do świeżo utworzonej armii, bejowie i agowie ponownie chwycili za broń. Przywódcą buntowników był niegdysiejszy współpracownik H. Gradaščevicia Ali pasza Fidahić, który jednak nie zdołał odnieść żadnego sukcesu na polu walki. Wojska osmańskie brutalnie stłumiły próby buntu. Kolejna fala niezadowolenia wybuchła po opublikowaniu Hatt-i Sharifu, wydanego w 1839 roku przez Abdülmecida I, który zapoczątkowało okres tzw. tanzimatu. Wydarzenie to wzburzyło także chrześcijan, którzy zgodnie z przesłaniem sułtańskiego edyktu domagali się równouprawnienia. $\mathrm{Z}$ kolei muzułmanie obawiali się ograniczenia swoich praw wskutek dopuszczenia niewiernych do spraw publicznych. Chaos w Bośni panował do 1847 roku, jego symptomem były częste zmiany na stanowisku wezyra, średnio co dwa lata. Falę niezadowolenia wywołały próby przeprowadzenia ograniczonej reformy rolnej. Na tamtejszej wsi niepodzielnie panował ustrój feudalny, który dyskryminował najczęściej chrześcijańskich chłopów i był dalece niewydajny ${ }^{36}$. Aby zmusić bejów do posłuszeństwa i zreformować stosunki panujące na prowincji, późnym latem 1847 roku sułtan oddelegował do Travnika na stanowisko wezyra Mehmeda Tahira paszę. Miał on opinię człowieka surowego, wręcz okrutnego, ale i bardzo oddanego programowi reform. Zdołał nieco poprawić sytuację prawną chłopstwa i podjął działania w kierunku stworzenia nowoczesnej administracji w której mieli znaleźć zatrudnienie zarówno muzułmanie, jak i przedstawiciele innych wyznań. Co nietypowe dla ówczesnych czasów, starał się także prowadzić konsultacje na temat poprawy losu chłopstwa, zapraszając do stołu przedstawicieli wspólnot (miletów) katolickich i prawosławnych. Ze względu na niepokoje związane z Wiosną Ludów w monarchii Habsburgów, na

34 Biskup Rafael Barišić (1796-1863) został w 1840 roku wysłany jako wikariusz apostolski do Bośni i Hercegowiny, co nie spodobało się tamtejszym franciszkanom, sprzeciwiającym się próbom podważenia ich pozycji wśród katolików na tym terenie. Dzięki wsparciu Rizvanbegovicia został ostatecznie wikariuszem w Hercegowinie: И. Кецмановић, Баришићева афера: прилог проучаваюу историје Босне и Хериеговине у првој половини ХІХ вијека, Sarajevo 1954.

35 H. Kapidžić, Ali-paša Rizvanbegović i nijegovo doba, s. 111. W trakcie wojny prowadzonej z Czarnogórą na początku lat czterdziestych XIX w., S. Rizvanbegović, obawiając się licznych migrantów czarnogórskich przybywających do Mostaru, nakazał ponad trzystu chrześcijańskim rodzinom opuścić miasto. Spotkało się to z oburzeniem ze strony katolików, którzy szukali pomocy u miejscowego konsula austriackiego: I. F. Jukić, Kratki pogled na Hercegovinu, [w:] I. F. Jukić, Putopisi i istorijsko-etnografski radovi, Sarajevo 1953, s. 398-399; H. Grandies, Multikonfesjonalna Hercegovina, s. 247-248; J. Branković, Mostar, s. 43-45.

36 A. Čuvalo, Historical dictionary of Bosnia and Hercegovina, London 1997, s. 20; G. Šljivo, Omer Paša-Latas, Sarajevo 1977, s. 10; S. S. Shaw, E. K. Shaw, Historia Imperium Osmańskiego i Republiki Tureckiej, s. 105; M. Imamović, Historija države i prava, s. 229-230. 
rozkaz wezyra przeprowadzono rekrutację męskiej młodzieży, zarówno muzułmanów jak i chrześcijan, do miejscowych oddziałów wojskowych. Ponadto ściągnięto osmańskich żołnierzy z innych europejskich prowincji ${ }^{37}$.

Działania Tahira paszy, mające na celu równouprawnienie chrześcijan w urzędach i w strukturach wojska frustrowały uprzywilejowanych bejów. Dali oni upust swojemu niezadowoleniu w 1849 roku, gdy w regionie Bosanska Krajina doszło do buntu, który wkrótce rozlał się na całą Bośnię i Hercegowinę. Zdaniem biografa S. Rizvanbegovicia Hamdiji Kapidžicia, hercegowiński wezyr nie był bezpośrednio zaangażowany w te działania, ale i nie odnosił się z wrogością do buntowników. Zależało mu na wyeliminowaniu skutków reform w duchu tanzimatu, realizowanych w sąsiedniej Bośni przez wezyra Tahira paszę. Uważał on, że były one skierowane nie tylko przeciwko samowolnym dotychczas janczarom czy kapetanom, ale realizowano je kosztem bogatych posiadaczy ziemskich, do których S. Rizvanbegović się zaliczał. Z drugiej strony starał się on nie występować bezpośrednio przeciwko wezyrowi bośniackiemu. Walki związane z powstaniem szybko wygasły, ponieważ obie strony zostały zdziesiątkowane wskutek epidemii cholery ${ }^{38}$. Ostatecznie bunt został spacyfikowany przez następcę Tahira paszy, Hafiza Mehmeda paszę, głównie za sprawą dowódcy wojskowego Omera paszy Latasa, który przybył do Bośni w 1850 roku z jasno określonym celem — miał ostatecznie spacyfikować niepokornych bejów. Posiadał on niezbędne doświadczenie i kwalifikacje, wcześniej pacyfikował powstania w innych prowincjach osmańskich, poza tym jako ,poturczeniec” o pochodzeniu serbskim był obeznany ze specyfiką Bośni i Hercegowiny. Nie bez znaczenia było pochodzenie jego najbliższych współpracowników, którzy tworzyli trzon dowódczy oddziałów stacjonujących w Bośni. Stosunkowo duży był tam udział konwertytów, zwłaszcza Węgrów i Polaków. Nie byli oni powiązani z miejscowymi rodami czy układami politycznymi, co przekładało się na ich lojalność względem sułtana. Długo jeszcze po wydarzeniach z przełomu 1850 i 1851 roku w Bośni i Hercegowinie pamiętano o byłym agencie Hotelu Lambert Antonim Ilińskim, który służył w armii sułtańskiej jako Iskander pasza Iliński. Był uznawany za doświadczonego żołnierza, ale i ,skandalistę", jako że nie stronił od alkoholu, a także dopuszczał się niszczenia świątyń muzułmańskich. Jednym z pacyfikatorów bejów i agów z Hercegowiny był z kolei Muhamed Skanderbeg, czyli Aleksander Łaski. Łącznie u boku O. Latasa służyło nawet kilkunastu żołnierzy polskiego pochodzenia ${ }^{39}$.

37 Prijatel A. do Ivo Vuleticha (25.08.1847), [w:] G. Šljivo, Bosna i Hercegovina u XIX stoljeću u spisama stranih izvještača, s. 144-145; G. Martić, Zapamćenja, Zagreb 1906, s. 9-10; G. Šljivo, Omer Paša-Latas u Bosni i Hercegovini, s. 20, 25-26, 33.

38 H. Kapidžić, Ali paša Rizvanbegović, s. 123; Prijatel A. do Ivo Vuleticha 02.09.1849, [w:] G. Šljivo, Bosna i Hercegovina u XIX stoljeću u spisama stranih izvještača, s. 174.

39 Zob. J. S. Łątka, Lew nasz, lew polski. Pasza Iskender (Antoni Iliński), Kraków 1996; A. Jabłonowski, Pisma, s. 102; I. Andrić, Omer pasza Latas, Warszawa 1968. Więcej na temat Polaków walczących u boku Omera paszy Latasa przeciwko bośniackim bejom: P. Dobrołęcki, Udział Polaków w walkach wewnętrznych w Bośni w latach 1850-1851, „Balcanica Posnaniensia” 1993, t. 7, s. 79-86. 
Wkrótce po przybyciu do Bośni Omer pasza Latas wezwał najważniejszych bejów, w tym S. Rizvanbegovicia. Zwyczajowo wezyr z Hercegowiny delegował na tego typu spotkania swojego syna, ale tym razem stawił się osobiście, nie chcąc narazić się komendantowi ${ }^{40}$. Przybyli wysłuchali fermanu sułtańskiego i otrzymali rozkaz uszanowania zasad tanzimatu. Pod nieobecność wezyra hercegowińskiego w Mostarze wybuchł bunt, który szybko objął inne części kraju, skłaniając Omera paszę do interwencji zbrojnej. Komendant postanowił wykorzystać tę okazję, aby ostatecznie wyeliminować S. Rizvanbegovicia z rozgrywek politycznych. Oskarżył leciwego wezyra o spiskowanie przeciwko sułtanowi. Wkroczył ze swoimi oddziałami do Mostaru, niszcząc miasto i jego okolicę. Wkrótce uwięził S. Rizvanbegovicia, który wskutek rzekomego nieszczęśliwego wypadku został raniony w głowę i zmarł. Jego śmierć stanowiła symboliczne zakończenie burzliwego, dwudziestoletniego okresu niepokojów antysułtańskich wśród bejów z Hercegowiny i Bośni. Omer pasza Latas zdołał zaprowadzić względny spokój, który trwał przez kolejnych dwadzieścia pięć lat. Dokonał tego w ogniu brutalnej walki z wszelkimi przejawami oporu ze strony miejscowych bejów ${ }^{41}$. Władza wezyrów przetrwała w Bośni jeszcze przez ponad ćwierć wieku.

Sprzeciw społeczności islamskich wobec prób reformowania XIX-wiecznej Turcji osmańskiej w kierunku centralizacji władzy był głęboko zakorzeniony w charakterystyce geopolitycznej oraz kulturowej Bośni i Hercegowiny. Tamtejsze elity broniły swoich przywilejów, wspierając się na tradycyjnych powiązaniach społecznych i korzystając z tego, że wielu miejscowych muzułmanów znajdowało się w stanie gotowości bojowej ze względu na sytuację w strefie przygranicznej. Po złamaniu oporu w 1831 i 1851 roku duża część elit, stojących na czele społeczności muzułmańskiej w Bośni i Hercegowinie na trwałe odwróciła się od władzy sułtańskiej. Duży wpływ na to miały wspomnienia o brutalnych działaniach oddziałów dowodzonych przez Omera paszę Latasa, które dotknęły nie tylko stronników powstania, ale i niezwiązaną z nimi ludność cywilną. Klęskę poniosła wizja stworzenia pod władzą Osmanów autonomicznej Bośni, wraz aktywizacją słowiańskich ruchów narodowych, na gruncie bośniackim pojawiły się pierwsze próby w kierunku stworzenia odrębnej tożsamości miejscowych muzułmanów-Słowian. We wzajemnych relacjami w ramach zróżnicowanej religijnie ludności coraz większą rolę odgrywały konotacje etniczne. Stało się to szczególnie widoczne w okresie rządów austro-węgierskich (1878-1918), gdy poszczególne środowiska intelektualne i religijne formułowały różne koncepcje odrębności muzułmańskiej w Bośni, a także funkcjonowały w różnych kontekstach

40 Omer Paša i bosanski Turci, „Bosanski prijatelj” 1861, nr 3, s. 44.

41 Prijatel A. do Ivo Vuleticha (27.10.1850), [w:] G. Šljivo, Bosna i Hercegovina u XIX stoljeću u spisama stranih izvještača, s. 235-236; H. Grandiits, Multikonfesjonalna Hercegovina, s. 76-77; List konsula Atanackovića do księcia Szwarcenberga (05.06.1851), [w:] Ivan Franjo Jukić. Dokumentarna građa, red. M. Mirljanović, A. Liljak, Sarajevo 1970, s. 163-164. 
chorwackiego i serbskiego życia narodowego. Choć antyosmańskie bunty w Bośni z pierwszej połowy XIX wieku miały ograniczony wpływ na konkretyzację odrębnych postaw etniczno-regionalnych wśród miejscowych muzułmanów, to jednak stanowiły zapowiedź zmian tożsamościowych, które z pełną mocą zaistniały w życiu społeczno-politycznym na początku XX wieku² ${ }^{42}$.

\section{BIBLIOGRAFIA}

\section{Źródla opublikowane}

Čaušević D., Pravno-politički razvitak Bosne i Hercegovine. Dokumenti sa komentarima, Sarajevo 2005. Ivan Franjo Jukić. Dokumentarna građa, red. M. Mirljanović, A. Liljak, Sarajevo 1970.

Jabłonowski A., Pisma Aleksandra Jabłonowskiego. Tom V Stowiańszczyzna południowa oraz Wołosza i Albania, Warszawa 1911.

Jukić I. F., Putopisi i istorijsko-etnografski radovi, Sarajevo 1953.

Ljubušak M. K., Muslimani u Bosni i Hercegovini, Sarajevo 2008.

Martić G., Zapamćenja, Zagreb 1906.

Šljivo G., Bosna i Hercegovina u XIX stoljeću u spisama stranih izvještača, Tešanj 2008.

\section{Czasopisma}

„Dziennik Poznański”, 1875.

„Kurier Poznański”, 1875.

„Bosanski prijatelj”, 1861.

\section{Opracowania}

Ademović F., Princ Palikuća u Sarajevu, Sarajevo 1997.

Aličič A., Pokret za autonomije Bosne od 1831. do 1832. godine, Sarajevo 1996.

Andrić I., Omer pasza Latas, Warszawa 1968.

Antić Č., Kecmanovića H., Istorija Republike Srpske, Banja Luka 2016 [Антић Ч., Кецмановића Н., Историја Републике Српске, Бања Лука 2016].

Benson L., Jugosławia. Historia w zarysie, Kraków 2011.

Bonarek J., Czekalski T., Sprawski S., Turlej S., Historia Grecji, Kraków 2005.

Branković J., Mostar 1833-1918, Sarajevo 2009.

Corović V., Bosna i Hercegovina, Beograd 1925.

Čuvalo A., Historical dictionary of Bosnia and Hercegovina, London 1997.

Đaković L., Političke organizacije bosanskohercegovačkih katolika Hrvata, (I dio: do otvaranja Sabora 1910), Zagreb 1985.

Đorđević D., Istorija moderne Srbije 1800-1918, Beograd 2017 [Ђорђевић Д., Историја модерне Србије 1800-1918, Београд 2017].

Dobrołęcki P., Udziat Polaków w walkach wewnętrznych w Bośni w latach 1850-1851, „Balcanica Posnaniensia", 1993, nr 7, s. 79-86.

Durkowicz-Jakszicz L. (L. Durković-Jakšič), Petar II Petrović-Njegoš (1813-1851), Warszawa 1938.

Džaja S., Konfesjonalnost i nacjonalnost Bosne i Hercegovine. Predemancipijsko razdoblje 1463-1804, Mostar 1999.

Gibas-Krzak D., Bośnia i Hercegowina: Determinanty dziejów. Pomiędzy Serbami, Chorwatami a supremacja muzulmanów, Częstochowa 2016.

42 Por. M. K. Ljubušak, Muslimani u Bosni i Hercegovini, Sarajevo 2008. 
Gibas-Krzak D., Zmierzch panowania tureckiego na Bałkanach. Polityczne, społeczno-kulturowe i militarne uwarunkowania schyłku władania Bośnia i Hercegowina przez Osmanów, „Balcanica Posnanensia. Acta et studia" 2015, t. 22, nr 2, s. 15-36.

Grandits H., Multikonfesjonalna Hercegovina. Vlast $i$ lojalnost u kasnoosmanskom društvu, Sarajevo 2014.

Hadžijahić M., Bune i ustanak u Bosni sredinom XVIII stoljeća, „Historijski zbornik” 1980-1981, t. 3334, s. 99-137.

Handžić M., Islamizacija Bosne i Hercegovine i porijeklo bosansko-hercegovačkih muslimana, Sarajevo 1940.

Imamović M., Historija Bošnjaka, Sarajevo 2007.

Heraclides A., Dialla A., Humanitarian intervention in the long nineteenth century, Manchester 2015.

Hickok M. R., Ottoman military administration in eighteenth-century Bosnia, Leiden-New York-Köln, 1997.

Imamović M., Historija države i prava u Bosni i Hercegovini, Sarajevo 1999.

Jawoszek-Goździk A., Bejowie, [w:] Leksykon idei wędrownych na słowiańskich Bałkanach, XVIIIXXI wiek, red. G. Szwat-Gyłybowa, D. Gil, L. Miodyński, t. 10, Warszawa 2020, s. 23-26.

Jelavich B., Historia Batkanów wiek XVIII i XIX, Kraków 2005.

Jezernik B., Dzika Europa. Bałkany w oczach zachodnich podróżników, Kraków 2007.

Kamberović H., Husein-Kapetan Gradaščević (1802-1834). Biografija, Gradačac 2002.

Kapidžić H., Ali-paša Rizvanbegović i nijegovo doba, Sarajevo 2001.

Karčić F., Studije o šerijatskom pravu i institucijama, Sarajevo 2011.

Kecmanović I., Barišićeva afera: prilog proučavanju istorije Bosne i Hercegovine u prvoj polovini XIX vijeka, Sarajevo 1954 [Кецмановић И., Баришићева афера: прилог проучаваюу историје Босне и Хериеговине у првој половини ХІХ вијека, Сарајево 1954].

Kreševljaković H., Husejn kapetan-Gradaščević. Zmaj od Bosne, Sarajevo 1931.

Kreševljaković H., Kapetanje u Bosni i Hercegovini, [w:] H. Kreševljaković, Izabrane djela I, Sarajevo 1991.

Kujawa K., ,Smok z Bośni” w tradycji bośniackich muzułmanów wczoraj i dziś, „Balcanica Posnanensia. Acta et studia" 2010, nr 17, s. 183-192.

Kujraković N., Vakuf Husein-Kapetana Gradaščevića, „Anali Gazi-husref begove biblioteke” 2009, nr 29-30, s. 65-98.

Lis T. J., Bosna i Hercegovina u očima Poljaka — poljski putopisi o Bosni i Hercegovini u Austrongarskom razdoblju, „Prilozi. Univerzitet u Sarajevu. Institut za Historiju” 2018, nr 48, s. 91-105.

Łątka J. S., Lew nasz, lew polski. Pasza Iskender (Antoni Iliński), Kraków 1996.

Maier L., Die Grenze zwischen dem Habsburgerreich und Bosnien um 1830. Von einem Versuch, eine friedlose Region zu befriede, „Jahrbücher für Geschichte Osteuropas”, 2003, nr 51, s. 379-391.

Malcolm N., Bosnia: a short history, London 1994.

Malečkova J., ,, The Turk” in the Czech imagination (1870s-1923), Leiden-Boston 2020.

Močanin N., Postanak muslimanskog plemstva u Bosni i Hercegovini: zanemirani aspekti, „Rad Hrvatske akademije znanosti i umjetnosti. Razred za društvene znanosti” 2017, nr 529, s. 73-94.

Morawski W., Szawłowska S., Wojny rosyjsko-tureckie od XVII do XX wieku, Warszawa 2006.

Omer Paša i bosanski Turci, „Bosanski Prijatelj” 1861, nr 3, s. 44.

Pavlowitch S. K., Historia Bałkanów (1804-1945), Warszawa 2010.

Pelc M., Utilissimus reipublicae princeps Eugen Savojski i retorika barokne medalje, „Radovi Instituta za povijest umjetnosti" 2020, nr 44/1, s. 89-108.

Pelidija E., O Bošnjačkoj eliti XVIII stoljeća, „Znakovi vremena” 2005, nr 26-27, s. 126-147.

Protopsaltis E. G., Byron and Greece, [w:] Byron's political and cultural influence in the nineteenth-century Europe, red. P. G. Trueblood, London 1981, s. 91-107.

Rawski T., Boszniacki nacjonalizm. Strategia budowania narodu po 1995 roku, Warszawa 2019.

Said E. W., Orientalizm, Warszawa 1991.

Šehić S., Zmaj od Bosne. Husein-Kapetan Gradaščević između legende i povijesti, Wuppertal 1994. 
Sel Turhan F., The Ottoman Empire and the Bosnian uprising. Janissaries, modernisation and rebelion in the nientieenth century, London-New York 2014.

Shaw S. S., Shaw E. K., Historia Imperium Osmańskiego i Republiki Tureckiej, Warszawa 2012.

Šljivo G., Omer Paša-Latas, Sarajevo 1977.

Stryjek T., Wspótczesna Serbia i Chorwacja wobec własnej historii, Warszawa 2020.

Wróbel P., Kontrowersje wokót podboju i islamizacji Bośni. Przyczynek do krytyki tzw. „Polityki historycznej”, „Balcanica Posnaniensia. Acta et studia” 2012, t. 19, s. 85-93.

Wróbel P., Krzyż i Pótksiężyc. Zachodnie Bałkany wobec Turcji w latach 1444-1463, Kraków 2000.

Wróbel P., Oblicza islamizacji na terenach Bośni w XV i 1. połowie XVI wieku, „Balcanica Posnaniensia. Acta et studia", XVIII, Poznań 2011, s. 83-100.

Žanin-Čalić M., Jugoistočna Europa. Globalna historija, Sarajevo 2020.

Zheliazkova A., The penetration and adaptation of islam in Bosnia from the fifteenth to the nineteenth century, ,Journal of Islamic Studies” 1994, nr 5/4, s. 187-208.

Zlatar B., Zlatno doba Sarajeva (XVI stoljeće), Sarajevo 1996. 